\title{
Assessment of Inflammatory Markers in Preeclampsia
}

\author{
${ }^{1}$ Prerna Bansal, ${ }^{2} \mathrm{I}$ Anand Shaker, ${ }^{3}$ Anupam K Bansal, ${ }^{4} \mathrm{GG}$ Kaushik
}

\begin{abstract}
Aim: Pregnancies, including preeclampsia, are low-grade systemic inflammation which has been associated with complications. Endothelial dysfunction in preeclampsia is accompanied by elevated levels of inflammatory markers and cytokines such as high sensitivity C-reactive protein (hs-CRP), tumor necrosis factor- $\alpha$ (TNF- $\alpha$ ) and interleukin-10 (IL-10). Our aim in this study is to assess the levels of these above markers in preeclampsia and to predict its severity.
\end{abstract}

Materials and methods: A case-control study was performed on 100 pregnant women with preeclampsia as cases (50 mild and 50 severe) as per clinical guidelines and 50 healthy pregnant women as controls. They were all age and parity-matched primigravidas at the third trimester of pregnancy.

Results: Significantly increased $(p<0.001)$ serum levels of hs-CRP, TNF- $\alpha$ and IL-10 were found in cases of mild and severe preeclamptic when compared to controls. In severe preeclamptics, all these parameters were also found highly significant in comparison to mild.

Conclusion and clinical significance: The observed high levels of hs-CRP, TNF- $\alpha$, and IL-10 in preeclamptic women indicate that these markers can be used in identifying the severity of preeclampsia and it can help the clinician in their diagnosis, treatment, and management.

Keywords: High sensitivity C-reactive protein (hs-CRP), Interleukin-10 (IL-10), Preeclampsia, Tumor necrosis factor- $\alpha$ (TNF- $\alpha$ ).

How to cite this article: Bansal $P$, Shaker IA, Bansal AK, Kaushik GG. Assessment of Inflammatory Markers in Preeclampsia. Indian J Med Biochem 2018;22(2):138-142.

\section{Source of support: Nil}

Conflict of interest: None

\section{INTRODUCTION}

Preeclampsia is one of the hypertensive disorders of pregnancy. It is a major cause of maternal and perinatal

\footnotetext{
${ }^{1}$ Assistant Professor, ${ }^{2,4}$ Professor and Head, ${ }^{3}$ Associate Professor

1,2Department of Biochemistry, Parul Institute of Medical Sciences and Research, Vadodara, Gujarat, India

${ }^{3}$ Department of Forensic Medicine, Parul Institute of Medical Sciences and Research, Vadodara, Gujarat, India

${ }^{4}$ Department of Biochemistry, Jawaharlal Nehru Medical College, Ajmer, Rajasthan, India
}

Corresponding Author: I Anand Shaker, Professor and Head, Department of Biochemistry, Parul Institute of Medical Sciences and Research, Vadodara, Gujarat, India, e-mail: prena309@gmail.com mortality and morbidity and is a pregnancy-specific hypertensive disease with multisystem involvement. It is a disorder of widespread vascular endothelial malfunction and vasospasm that occurs after 20 weeks of gestation and can present as late as 4 to 6 weeks postpartum. $^{1}$

Hypertension is one of the most common medical problem encountered during pregnancy, complicating up to $10 \%$ of pregnancies. ${ }^{2}$ Preeclampsia occurs in 3 to $6 \%$ of all pregnancies and the incidence is 1.5 to 2 times higher in first-time pregnancies. ${ }^{3}$ The incidence of preeclampsia has been increased by $25 \%$ in the United States during the past two decades. In India, the incidence of preeclampsia is reported to be 8 to $10 \%$ among pregnant women. According to Dubey L, the prevalence of hypertensive disorders of pregnancy was $7.8 \%$ with preeclampsia in $5.4 \%$ of the study population in India. Preeclampsia is a leading cause of maternal and perinatal morbidity and mortality, with an estimated 50000-60000 preeclampsia related deaths per year worldwide. ${ }^{4,5}$

Preeclampsia syndrome, in many cases, is thought to cause by a shallowly implanted placenta which becomes hypoxic, leading to an immune reaction characterized by secretion of upregulated inflammatory mediators from the placenta and acting on the vascular endothelium. ${ }^{6}$ It is characterized by widespread endothelial dysfunction throughout the maternal circulation resulting in hypertension attributable to vasoconstriction, proteinuria due to glomerular damage and edema as a result of increased vascular permeability. ${ }^{7}$ Inflammatory cells are activated in preeclampsia and localized to the site of vascular injury and associated with higher levels of pro-inflammatory molecules, cytokines, and adhesion molecules.

- One of the most important objectives and sensitive indexes of overall inflammatory activity in the body is hs-CRP. ${ }^{8}$ The hepatic synthesis of hs-CRP increases in response to inflammatory cytokines such as IL-10 and IL-6 which are responsible for inflammatory reactions and maternal endothelial activation in pre-eclampsia.9,10

- The IL-10 is a potent pleiotropic cytokine, which has the dual ability of immune-suppression or immune-stimulation via the production of proinflammatory cytokines by the inhibition of T-helper 1 (Th1) 1ymphocytes and stimulation of B and Th2 lymphocytes and thus downregulates the inflammatory response. ${ }^{11}$ 
- The TNF- $\alpha$ is a $17 \mathrm{kD}$ polypeptide cytokine produced in preeclampsia by neutrophils, monocytes, and placenta. Cytokines are involved in normal pregnancy and labor. It regulates trophoblast proliferation and differentiation, cell adhesion, tissue remodeling, apoptosis of villous trophoblast and trophoblast hormone production. ${ }^{12}$ The low level of uterine TNF- $\alpha$ is beneficial to pregnancy, whereas elevated concentrations are detrimental.

If preeclampsia is not diagnosed or treated timely, it can progress to maternal multi-organ failure, coagulopathy, intrauterine fetal demise and finally maternal death. So, being very sensitive markers of inflammatory activity in the body, determination of all these parameters can be used as a marker of low-grade inflammation and further help in detecting pathophysiological process in pregnancy, to predict adverse pregnancy outcome and try preventive therapies on time.

\section{MATERIALS AND METHODS}

The study was conducted at Mahila Chikitsalaya, Jawahar Lal Nehru Medical College and associated group of hospitals, Ajmer (Rajasthan) with prior ethical approval by institutional ethical experimentation committee and as per Helsinki declaration of 1975 that was revised in $2000 .^{13}$

A diagnosed case-control study with (age and paritymatched) 100 primigravidas of preeclampsia (50 mild and 50 severe) and 50 healthy primigravidas was done. Their gestational age was ranging from 28 to 40 weeks. They were grouped as follows:

Group I: 50 healthy pregnant women

Group II: 50 mild preeclamptic women

Group III: 50 severe preeclamptic women

\section{Inclusion Criteria}

All third-trimester primigravidas without any complications were included as controls.

All mild preeclamptic third-trimester pregnant women were taken according to American College of Obstetrics and Gynecology ACOG, 2013 criteria: (1) blood pressure $>140 / 90 \mathrm{mmHg}$ for two readings 6 hours apart; (2) proteinuria $>300 \mathrm{mg} / 24$ hours or +1 dipstick; (3) edema. ${ }^{14}$
All severe preeclamptic third trimester pregnant women were considered as ACOG, 2013 criteria (3) as: blood pressure $>160 / 110 \mathrm{mmHg}$ for two readings 6 hours apart, proteinuria $>5 \mathrm{gm} / 24$ hours or $+2,+3$ dipstick, serum creatinine $>1.2 \mathrm{mg} / \mathrm{dL}$, platelets $<100,000 / \mathrm{mm}^{3}$, microangiopathic hemolysis, elevated liver enzymes, epigastric pain or right quadrant pain, persistent headache or other cerebral or visual disturbances, intrauterine growth restriction (IUGR), pulmonary edema and oliguria.

\section{Exclusion Criteria}

Patients with multiple pregnancies, chronic hypertension, and premature rupture of membranes, symptomatic inflammatory diseases, diabetes mellitus, and chronic renal disease were excluded.

Anthropometric Measurements: Body human index (BMI) and mean arterial pressure were calculated.

Three $\mathrm{mL}$ blood sample and 24 hours urine sample of each subject were collected in a plain vial. The serum and urine samples were separated by centrifugation for 15 minutes at $1500 \mathrm{rpm}$. All the samples were stored at $-20^{\circ} \mathrm{C}$ for further analysis.

- Serum IL-10 and TNF- $\alpha$ concentrations were measured by sandwich enzyme-linked immunosorbent assay (ELISA) method (Bio-Rad Model 680 microplate reader and washer). ${ }^{15,16}$

- Serum hs-CRP and urinary protein levels were quantified by Immuno-turbidimetric assay and pyrogallol red method respectively. ${ }^{17,18}$

\section{Statistical Analysis}

All the data analysis was done by using Microsoft Excel and the Statistical Package for Social Science (SPSS) version 24.0 windows software, mean, standard deviation (SD) and analysis of variance (ANOVA) were calculated. The analysis was, and statistical results were considered significant at $\mathrm{p} \leq 0.05$.

\section{RESULTS}

The demographic profile of the study subjects is presented in Table 1 which shows the elevation in BMI and gestational age is nonsignificant.

The biochemical parameters of the subjects are tabulated in Table 2.

Table 1: Demographic profile of study subjects

\begin{tabular}{|c|c|c|c|c|c|c|c|}
\hline \multirow[b]{2}{*}{ Variables } & \multicolumn{2}{|c|}{ Group I $(n=50)$} & \multicolumn{2}{|c|}{ Group II $(n=50)$} & \multicolumn{2}{|c|}{ Group III $(C n=50)$} & \multirow[b]{2}{*}{$p$-value } \\
\hline & Mean $\pm S D$ & $95 \% \mathrm{Cl}$ & Mean $\pm S D$ & $95 \% \mathrm{Cl}$ & Mean $\pm S D$ & $95 \% \mathrm{Cl}$ & \\
\hline \multicolumn{8}{|l|}{ Gestational } \\
\hline Age (weeks) & $33.60 \pm 3.96$ & $32.81-34.39$ & $34.28 \pm 3.56$ & $33.65-34.91$ & $33.76 \pm 3.64$ & $32.92-34.60$ & 0.7 \\
\hline BMI $\left(\mathrm{Kg} / \mathrm{m}^{2}\right)$ & $29.68 \pm 5.41$ & $28.20-30.35$ & $30.08 \pm 6.65$ & $28.91-31.25$ & $29.88 \pm 6.08$ & $28.50-31.26$ & 0.3 \\
\hline
\end{tabular}


Table 2: Biochemical parameters showing the following results

\begin{tabular}{|c|c|c|c|c|c|c|}
\hline \multirow[b]{2}{*}{ Variables } & \multicolumn{2}{|c|}{ Group I $(n=50)$} & \multicolumn{2}{|c|}{ Group II $(n=50)$} & \multicolumn{2}{|c|}{ Group III $(n=50)$} \\
\hline & Mean $\pm S D$ & $95 \% \mathrm{Cl}$ & Mean $\pm S D$ & $95 \% \mathrm{Cl}$ & Mean $\pm S D$ & $95 \% \mathrm{Cl}$ \\
\hline MAP (mm Hg) & $83.92 \pm 12.17$ & $81.51-86.33$ & $115.16 \pm 17.64$ & $112.04-118.28$ & $133.12 \pm 24.61$ & $127.46-138.78$ \\
\hline $\begin{array}{l}\text { Urinary protein } \\
\text { (mg/ } 24 \text { hours) }\end{array}$ & $129.40 \pm 37.26$ & 0.234 & $1386.00 \pm 859.78$ & 4.822 & $4188.00 \pm 1417.26$ & 10.26 \\
\hline hs-CRP (mg/L) & $4.50 \pm 1.09$ & $4.28-4.71$ & $9.06 \pm 1.20$ & $8.84-9.27$ & $12.22 \pm 1.93$ & $11.77-12.66$ \\
\hline TNF- $\alpha(p g / m L)$ & $6.78 \pm 1.13$ & $6.55-7.00$ & $31.57 \pm 9.77$ & $29.84-33.30$ & $64.69 \pm 11.90$ & $61.95-67.43$ \\
\hline IL-10 (pg/mL) & $4.38 \pm 0.99$ & $4.18-4.58$ & $9.16 \pm 1.96$ & $8.80-9.50$ & $12.88 \pm 2.11$ & $12.39-13.36$ \\
\hline
\end{tabular}

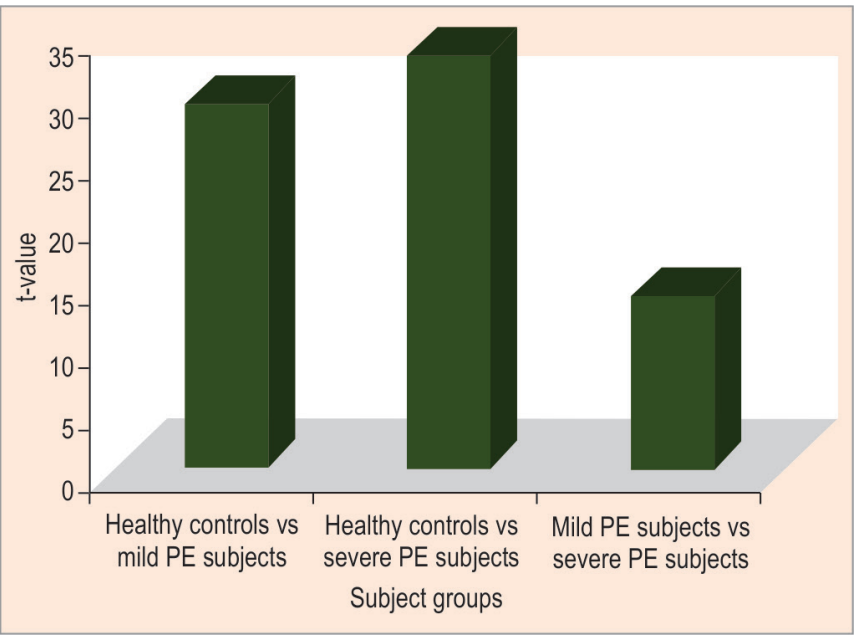

Fig. 1: Comparison of mean serum high sensitivity-C-reactive protein (mg/l) among various groups of subjects

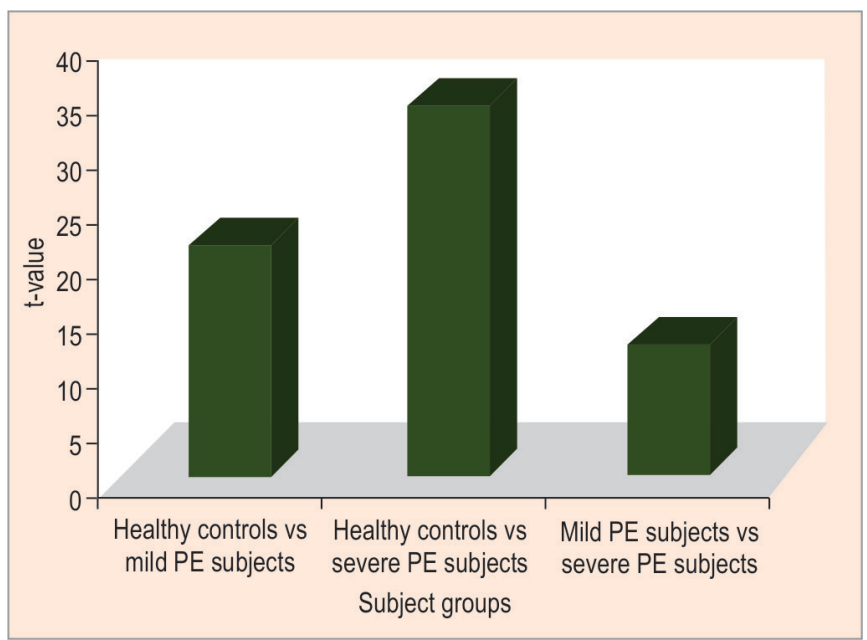

Fig. 3: Comparison of mean serum interleukin $(\mathrm{pg} / \mathrm{mL})$ among various groups of subjects

A significant elevation (according to ANOVA) in MAP, urinary protein, hs-CRP, TNF-alpha and IL-10 were observed in mild and severe preeclamptic women when compared in all groups as shown in Table 3. These data are also projected in Figures 1 to 3 .

Among the groups for each parameter, many with different letters horizontally have significant differences at $\mathrm{p} \leq 0.05$ using ANOVA.

The significantly high values $(\mathrm{p}<0.001)$ of hs-CRP, TNF- $\alpha$, and IL-10 levels were obtained in severely preec-

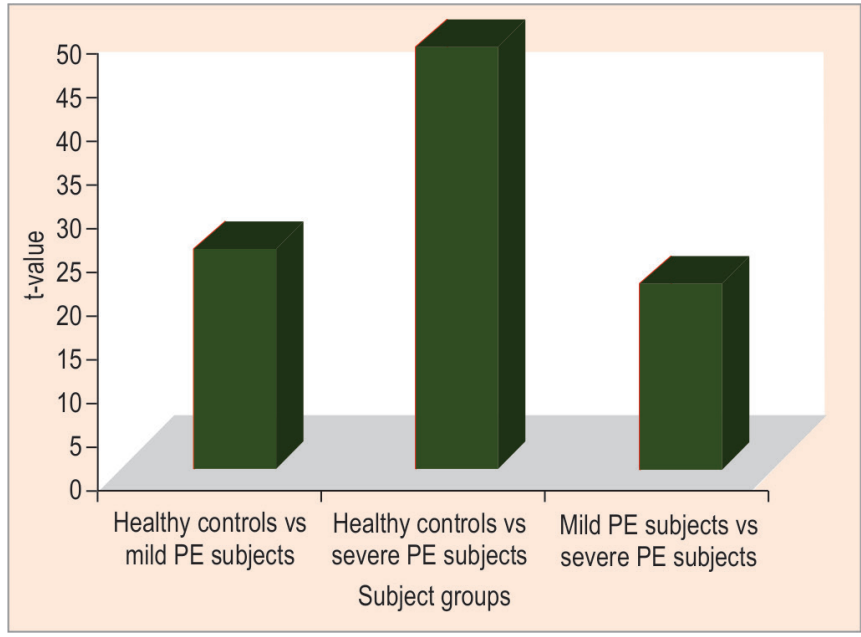

Fig. 2: Comparison of mean serum tumor necrosis factor-alpha $(\mathrm{pg} / \mathrm{mL})$ among various groups of subjects

lamptic patients compared to mild and healthy controls in the present study which signify that these parameters can be used for interpreting complications of pregnancy.

\section{DISCUSSION}

This study was carried out to examine the extent of inflammation in toxemia of pregnancy and also to evaluate the role of inflammatory markers in predicting the severity of preeclampsia. Because of the proposed influence of the maternal immune system on placentation and the subsequent systemic reactions, it is of great interest to study the maternal inflammatory response during preeclampsia in the hope of achieving a better understanding of this puzzling disease.

In the present study, serum hs-CRP in different groups were $4.5 \pm 1.09,9.06 \pm 1.20,12.22 \pm 1.93$ and this matches with the similar study conducted by Nanda et al. on 70 pregnant women which showed a mean level of $2.78 \pm$ 1.45 and the p-value $<0.001{ }^{19}$ Oancea et al. published a study with 120 pregnant women showed statistically significant hs-CRP levels in patients with preeclampsia compared to controls. ${ }^{20}$

Levels of serum TNF- $\alpha$ in control were $6.78 \pm 1.13$, in mild $31.57 \pm 9.77$ and severe preeclamptics were $64.69 \pm 11.90$ and our study matches with the study done by Fozia et al. which showed a significant increase 
Table 3: Comparison of biochemical variables among control and cases

\begin{tabular}{|c|c|c|c|c|}
\hline & Group 1 & Group 2 & Group 3 & \\
\hline Variables & Mean $\pm S D$ & Mean $\pm S D$ & Mean $\pm S D$ & $p$-value \\
\hline MAP $(\mathrm{mm} \mathrm{Hg})$ & $83.92 \pm 12.17$ & $115.16 \pm 17.64$ & $133.12 \pm 24.61$ & 0.0001 \\
\hline Urinary protein (mg/24 hours) & $129.40 \pm 37.26$ & $1386.00 \pm 859.78$ & $4188.00 \pm 1417.26$ & 0.0001 \\
\hline hs-CRP (mg/L) & $4.50 \pm 1.09$ & $9.06 \pm 1.20$ & $12.22 \pm 1.93$ & 0.0001 \\
\hline TNF- $\alpha(p g / m L)$ & $6.78 \pm 1.13$ & $31.57 \pm 9.77$ & $64.69 \pm 11.90$ & 0.0001 \\
\hline IL-10 (pg/mL) & $4.38 \pm 0.99$ & $9.16 \pm 1.96$ & $12.88 \pm 2.11$ & 0.0001 \\
\hline
\end{tabular}

One way ANOVA test was applied.

Among the group for each parameter means with different letters horizontally have significant difference at $p \leq 0.05$

in TNF- $\alpha$ level in preeclamptics. A study conducted by Sharma et al. showed a statistically significant increase in serum TNF- $\alpha$ in preeclamptics $(\mathrm{p}<0.001) .{ }^{21}$

Serum IL-10 values were $4.38 \pm 0.99,9.16 \pm 1.96$, $12.88 \pm 2.11$ in three groups respectively (Table 1 ). Fathollah et al. conducted a similar study in Iran and showed comparable results of TNF- $\alpha$ with our study $\mathrm{p}<0.001 .^{22}$ But considering the levels of IL-10, it is contradictory to what we have obtained in our study. In his study, the serum IL-10 levels were significantly high in normotensive pregnant women compared to preeclamptics. A study done by Lau et al. showed similar results with our study. The IL-10 levels in preeclamptics were significantly elevated. ${ }^{23}$ Jonsson et al. observed no significant difference in IL-10 levels between normotensive and pre-eclamptic women. ${ }^{24}$

The probable reasons for elevated pro-inflammatory markers like hs-CRP in preeclamptics, although some amount is associated with normal pregnancy, were reduced plasma volume and effect of BMI. ${ }^{25}$ Some studies proposed a direct effect of CRP on human endothelial cells by inducing expression of adhesion molecules. CRP may also contribute to thrombosis by inducing human monocytes to synthesize tissue factor, a potent procoagulant. ${ }^{26}$ These observations imply that a subclinical inflammation has a role in the pathogenesis of preeclampsia. ${ }^{27}$

Preeclamptic patients show an alarming increase proinflammatory cytokines like IL-10 and TNF- in their serum (Fig. 1) ${ }^{28}$ These inflammatory mediators promote systemic vascular damage, particularly in the kidney, results in the characteristic proteinuria and hypertension of the maternal syndrome of preeclampsia. ${ }^{29}$

Interleukin-10 (IL-10) and TNF- $\alpha$ markedly upregulate IL-messenger RNA (mRNA) and protein expression by the resident decidual cells. This augmented expression of decidual IL-10 may play a key role in the inflammation in preeclamptics. ${ }^{30}$

The high concentration of IL-10 in women with preeclampsia, as found in this study, maybe because preeclampsia is a manifestation of immune rejection, which IL-10 tries to suppress.

\section{CONCLUSION AND CLINICAL SIGNIFICANCE}

From the study mentioned above and many other studies, it was found that increased blood levels of inflammatory markers (hs-CRP, TNF- $\alpha$, and IL-10) reflect endothelial dysfunction with inflammatory process in the preeclamptic complication of pregnancy.

\section{REFERENCES}

1. Ambreen AA, Melinda H. Pre-eclampsia: systemic endothelial damage leading to increased activation of the blood coagulation cascade. Journal of Biotech. Research. 2012;4:26-43.

2. Wallis AB, Saftlas AF, Hsia AJ, Atrash HK. Secular trends in the rates of preeclampsia, eclampsia, and gestational hypertension, United States, 1987-2004. Am J Hypertens. 2008;21:521-526.

3. Ananth CV, Keyes KM, Wapner RJ. Pre-eclampsia rates in the United States, 1980-2010: age-period-cohort analysis. Bmj. 2013 Nov 7;347:f6564.

4. World Health Organisation. The world health report: 2005: make every mother and child count. Geneva: WHO; 2005. Available athttp://www.who.int/whr/2005/whr2005_en.pdf.Retrived March 20, 2013.

5. Dubey L. Maternal mortality associated with hypertensive disorders of pregnancy in Africa, Asia, Latin America and Caribbean. Br J Obstet Gynaecol. 1992;99:547-553.

6. Moffett A, Hiby SE. How does the maternal immune system contribute to the development of Preeclampsia? Placenta. 2007;4:51-56.

7. Roberts JM, Cooper DW. Pathogenesis and genetics of preeclampsia. The Lancet. 2001 Jan 6;357(9249):53-56.

8. Aziz SB. High sensitivity C-reactive protein in preeclamptic (PE) women. Medical Journal of Tikrit. 2015;20(1):55-62.

9. Tjoa ML, Van Vugt JM, Go AT, Blankenstein MA, Oudejans CB, Van Wijk IJ. Elevated C-reactive protein levels during first trimester of pregnancy are indicative of preeclampsia and intrauterine growth restriction. Journal of reproductive immunology. 2003 Jun 1;59(1):29-37.

10. Qui C, Luthy DA, Zhang C, Walsh SW, Leisenring WM, Williams MA. A prospective study of maternal serum C-reactive protein concentration and risk of preeclampsia. 2004;17(2): 154-160.

11. Sowmya S, Ramaiah A, Sunitha T, Nallari P, Jyothy A, Venkateswari A. Evaluation of Interleukin-10 (G-1082A) Promoter Polymorphism in Preeclampsia. Preeclampsia. J Reprod Infertil. 2013;14(2):62-66.

12. Patigaroo FA, Siddiqui AH, Gulati R, Mohsin Z. Tumor Necrosis Factor Alpha In Preeclampsia. International Journal of Basic and Applied Physiology. 2013;2(1):224-228. 
13. Diniz D, Corrêa M. The Helsinki Declaration: relativism and vulnerability. Cadernos de saude publica. 2001 Jun;17(3): 679-688.

14. Hypertension in Pregnancy. Obstetrics \& Gynecology [Internet]. Ovid Technologies (Wolters Kluwer Health); 2013 Nov;122(5):1122-1131.

15. Moore KW, O'Garra A, de Waal Malefyt R, Vieira P, Mosmann TR. Interleukin-10. Annu Rev Immunol. 1993;11:165-190.

16. Aderka D, Engelmann H, Maor Y, Brakebusch C, Wallach D. Stabilization of the bioactivity of tumor necrosis factor by its soluble receptors. Journal of Experimental Medicine. $1992 \mathrm{Feb}$ 1;175(2):323-329.

17. Otsuji S, Shibata H, Umeda M. Turbidimetric immunoassay of serum C-reactive protein. Clinical Chemistry. 1982 Oct 1;28 (10):2121-2124

18. Watanabe N, Kamei S, Ohkubo A, Yamanaka M, Ohsawa S, Makino K, Tokuda K. Urinary protein as measured with a pyrogallol red-molybdate complex, manually and in a Hitachi 726 automated analyzer. Clinical chemistry. 1986 Aug 1;32(8): 1551-1554.

19. Nanda K, Sadanand G, Muralidhara Krishna CS, Mahadevappa KL. C-reactive protein as a predictive factor of pre-eclampsia. Int J Biol Med Res. 2012;3(1):1307-1310.

20. Oancea MD, Costin N, Pop DM, Ciortea R, Trif I, Mihu D. Evaluation of Inflammatory Markers in Pregnant Women at Risk, for the Prediction of Preeclampsia. Acta Medica Marisiensis. 2014 Jun 1;60(3):94-98.

21. Sharma A, Satyam A, Sharma JB. Leptin, IL 10 and inflammatory markers (TNF , IL 6 and IL 8) in pre eclamptic, normotensive pregnant and healthy non pregnant women. American Journal of Reproductive Immunology. 2007 Jul 1;58(1):21-30.

22. Kalantar F, Rajaei S, Heidari AB, Mansouri R, Rashidi N, Izad $\mathrm{MH}$, et al. Serum levels of tumor necrosis factor- , interleukin-15 and interleukin-10 in patients with pre-eclampsia in comparison with normotensive pregnant women.
Iranian journal of nursing and midwifery research. 2013 Nov;18(6):463.

23. Lau SY, Guild SJ, Barrett CJ, Chen Q, McCowan L, Jordan V, et al. Tumor necrosis factor alpha, interleukin 6, and interleukin 10 levels are altered in preeclampsia: a systematic review and meta analysis. American journal of reproductive immunology. 2013 Nov;70(5):412-427.

24. Jonsson $Y$, Rubèr M, Matthiesen L, Berg G, Nieminen $K$, Sharma S, Ernerudh J, Ekerfelt C. Cytokine mapping of sera from women with preeclampsia and normal pregnancies. Journal of reproductive immunology. 2006 Jun 1;70(1-2): 83-91.

25. Vijayalakshmi P, Usha MR, Shetty HV, Priyadarshini KS, Victoria SH, Montey N. Study of serum hsCRP and lipid profile in pre-eclampsia. International Journal of Recent Trends in Science And Technology. 2015;14(3):605-609.

26. Kanak KM, Arpita D, Lakhipyari D, Omita N, Nabakishore $\mathrm{S}$, Singh WG. Serum high sensitivity $\mathrm{C}$ - reactive protein as predictor of Preeclampsia. IOSR-JDMS. 2016;15(2):26-31.

27. Rifai N, Ridker PM. Population distributions of C-reactive protein in apparently healthy men and women in the United States: implication for clinical interpretation. Clinical Chemistry. 2003 Apr 1;49(4):666-669.

28. Xie C, Yao MZ, Liu JB, Xiong LK. A meta-analysis of tumor necrosis factor-alpha, interleukin-6, and interleukin-10 in preeclampsia. Cytokine. 2011;56(3):550-559.

29. Celik H, Avi B, Alper T. Comparison of maternal serum levels of interleukin-10, interleukin-12, and interleukin-2 in normal and pre-eclamptic pregnancies. Pregnancy Hypertens Int J Women Cardiovasc Health. 2012;2:39-42.

30. Haedersdal S, Salvig J, Aabye M, Christian W, Thorball, Ruhwald M, et al. Inflammatory Markers in the Second Trimester Prior to Clinical Onset of Preeclampsia, Intrauterine Growth Restriction, and Spontaneous Preterm Birth. Inflammation. 2013;4:907-913. 